\title{
Non-destructive in situ spectroscopic analysis of greenstone objects from royal burial offerings of the Mayan site of Palenque, Mexico
}

\author{
Alma A. Delgado Robles ${ }^{1}$, Jose Luis Ruvalcaba Sil ${ }^{1 *}$, Pieterjan Claes ${ }^{1}$, Mayra D. Manrique Ortega ${ }^{1}$, \\ Edgar Casanova González ${ }^{1,2}$, Miguel Ángel Maynez Rojas ${ }^{1}$, Martha Cuevas García ${ }^{3}$ and Sabrina García Castillo ${ }^{3}$
}

\begin{abstract}
One of the most important Mayan cities of the Classic period (A.D. 200-900) of Mesoamerica is Palenque, in Chiapas. The Mayan civilization attributed great importance to greenstone minerals, in particular jadeite. This study covers the analysis of greenstones found in royal tombs of several temples corresponding to the Classic period: the Temple of the Skull, Temple of the Cross and Temples XVIII and XVIII-A. The aim of this research is to determine the use of greenstone minerals and the raw materials' sources as a first step in understanding the development of Palenque and its relationships to other sites in the Maya region. Here, we present a non-destructive in situ study of lithic objects carried out by means of a several spectroscopic techniques, such as Raman, Fourier transform infrared (FTIR), X-ray fluorescence (XRF) and color measurements, at the Palenque site museum. FTIR and Raman allowed for the identification of minerals including jadeite, omphacite, amazonite, albite, muscovite and green quartz. Moreover, XRF was effective for in situ analysis of the elemental composition of the artifacts. This information was essential for sourcing the raw materials, in particular, jadeite. It was possible to infer the exploitation of an unknown source of jadeite for the earlier burial (A.D. 250-450). During this period the exploitation of the Verapaz and Motagua jadeite deposits also began. These sources were the primary deposits used for the manufacture of the artifacts studied from the period of A.D. 600-850. Also, a greater diversity of minerals is observed during the zenith of Palenque during this period, corresponding to the reign of Pakal. Although, between burials, the color of the artifacts is diverse, the color measurements indicated similarity in color among artifacts within individual burials.
\end{abstract}

Keywords: In situ, FTIR, Raman, XRF, Color, Palenque, Green minerals

\section{Background}

Cultural heritage materials are highly valuable for humanity due to their historical importance. Thus their study requires special care in order to ensure their preservation. The information gleaned from material characterization can be useful for future investigations. Furthermore, many cultural heritage items cannot be easily moved from their location; thus the need to develop in situ analyses with portable equipment is highly

\footnotetext{
*Correspondence: sil@fisica.unam.mx

${ }^{1}$ Instituto de Fisica, Universidad Nacional Autónoma de México, Circuito de la Investigación Científica s/n, Ciudad Universitaria, C.P. 04510 Mexico City, Mexico

Full list of author information is available at the end of the article
}

important. For this reason, portable and non-destructive spectroscopic techniques have become powerful tools to analyze the structure and properties of materials of cultural and historical value. In this work, spectroscopic techniques, such as Fourier transform infrared (FTIR), Raman, X-ray fluorescence (XRF) and color measurements have been applied in situ to study lithic archaeological artifacts. These techniques are complementary to each other and they provide information at an atomic level (XRF), while others give insight into the molecular structure (Raman and FTIR). They can be applied to study a diverse range of objects, including polychrome works, ceramics, inks, stamps, alloys or stone artifacts, and other valuable materials [1]. The information obtained from the study of these artifacts can provide

\section{Chemistry Central}


relevant information on the development of a certain society and its relationships, such as the possible ways in which its culture and technology propagated.

In terms of vibrational spectroscopy, Fourier transform infrared spectroscopy (FTIR) represents a powerful non-destructive technique for diagnostic and conservation of archaeological items. The technique permits the identification of characteristic vibrations associated with functional groups in a given molecule [2]. Raman spectroscopy, being non-destructive, fast, sensitive, reproducible and less expensive than other techniques is being increasingly used for artwork analyses [3], in particular for pigment identification. Raman spectroscopy in fact complements the FTIR analysis [4]. Additionally, in terms of atomic spectroscopy, X-ray fluorescence is the most widely employed technique for quantitative elemental analysis in the field of archaeometry due, among other factors, to its portability, non-invasive nature and multi-element identification capabilities $[5,6]$. On the other hand, colorimetric techniques are employed to measure and determine in an objective way the color of a given sample as a function of its interaction with light [7].

\section{Archaeological context}

Palenque is located in the north of the state of Chiapas, Mexico, in a region with a high abundance of water, hence the site's original name of Lakamha ("Big Water"). This city-state was one of the most influential during the Classic period (A.D. 200-900) in this region [8]. Four temples of this city (namely the Temples of the Skull, the Cross, XVIII and XVIII-A) are particularly relevant for this project because of the quality and amount of greenstones found at the excavated burials (Figure 1). Some of the constructions in Palenque were built on the remains of other previous structures that most likely were sacred zones of great importance. This fact confirms that there were periods of reconstruction and renovation of the Mayan temples. This study focuses on the burials found in the temples of the Cross Group, the Great Plaza, and the ones in the South Acropolis (South of the Cross Group). The chronology of these temples was established from pottery remains and stratigraphy.

The South Acropolis group was a very important ceremonial zone in the city. It consists of the temples XVIII which was built (A.D. 600-850) over the foundations of earlier Classic buildings and XVIII-A (A.D. 250-450) where the oldest burial was discovered.

The Cross Group is composed of three important ceremonial temples that constitute the core of this section: the Temple of the Foliated Cross, the Temple of the Sun and the Temple of the Cross (A.D. 300-600). These temples were built to honor the Palenque Triad, the gods

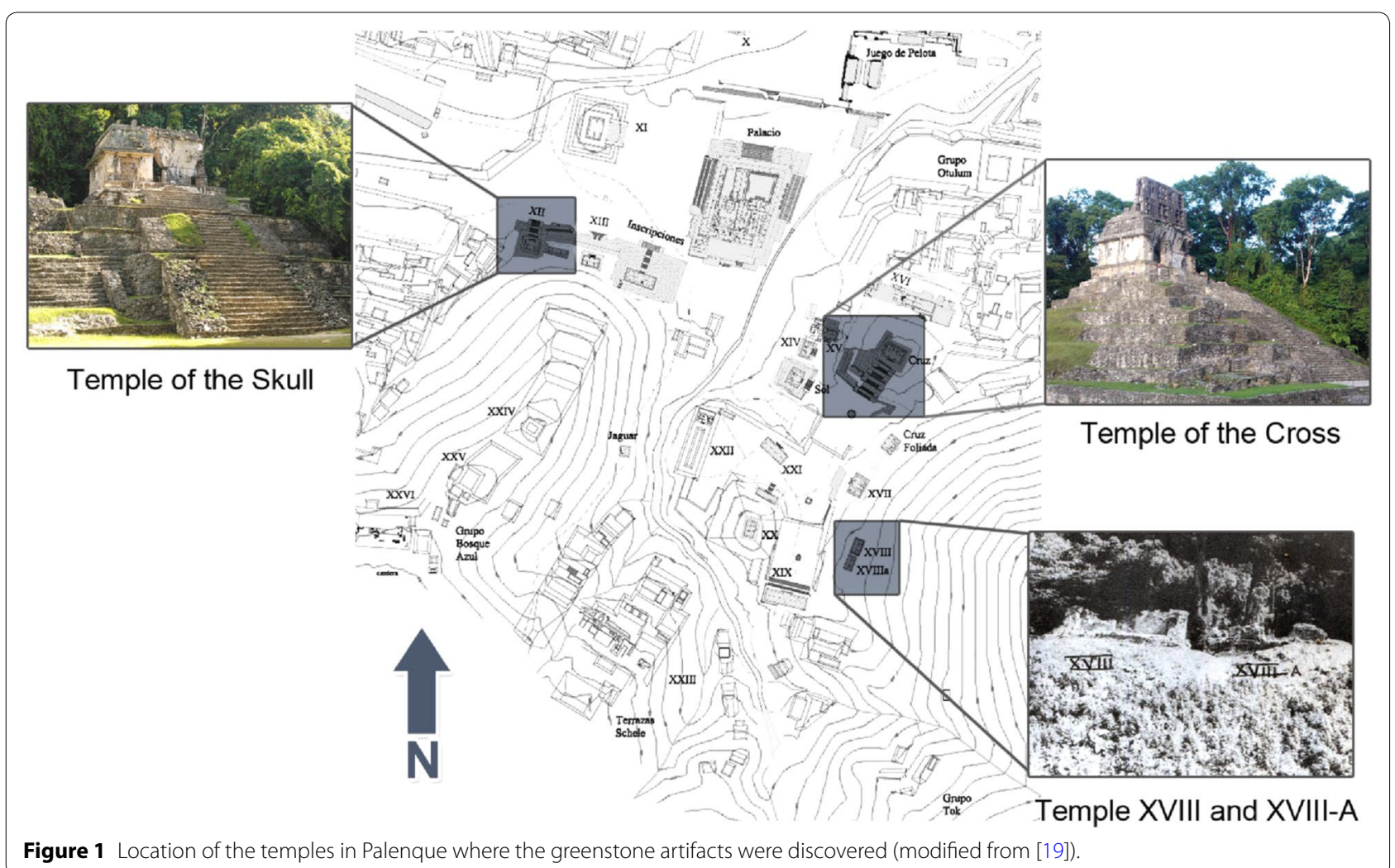


referred to as GI, GII y GIII. Their architectonic reconstruction was carried out during the late Classic period, more specifically between 600 and 900 [9-13].

The Temple of the Skull (A.D. 700-770) is located at the Great Plaza which is considered the Imperial necropolis of Palenque, where the Palace is. It was erected in the South part of the Plaza next to the Temple of the Inscriptions where the famous Great Pakal tomb was found, the Temple XIII where the Red Queen was buried and the Temple XII-A. The Temple of the Skull has a substructure called the Dark Temple [12].

The analytical examination of Mayan greenstones represents an interesting subject of study since their presence assigns higher importance to an elite burial and a temple. Greenstones were said to ease the transit of the deceased in their journey and this would explain their presence in many royal burials. These artifacts have been found in burial sites of several Mayan cities, such as Palenque, Petén, Calakmul, Uaxactún or Copán, just to mention a few examples [14, 15].

They were highly valued in Mesoamerican societies, specifically jadeite which can be associated with albite, omphacite and quartz, as they represented power, fertility and even life itself [16]. Jadeite stones have their origin in basic igneous rocks that underwent a process of metamorphism due to the tectonic plates' collisions in the Motagua fault in Guatemala. This is a unique region in Mesoamerica with the required geological conditions for jadeite formation $[17,18]$.

The materials studied are housed in the Museum of the Archaeological Site in Palenque, Chiapas. For this research, we studied three objects from tomb 3 in the Temple XVIII-A dated between A.D. 250 and 450. The 15 pieces of tomb 5 located in the Temple of the Cross (dated between A.D. 300 and 600), and the pieces recovered from tomb 2 in Temple XVIII, where both graves have a date from A.D. 600 to 850 A.D, were also included in the analysis. The five pieces from tomb 1 located in a substructure of the Temple of the Skull (A.D. 770-770), including one with an inscription corresponding to A.D. 697, were also analyzed.

\section{Methods}

In this work, we studied vibrational, elemental and color properties, using the following portable techniques:

\section{Fourier transform infrared spectroscopy (FTIR)}

The FTIR portable equipment used in this research was an Alpha spectrometer by Bruker Optics, corresponding to the spectral region between 400 and $4000 \mathrm{~cm}^{-1}$. It includes a camera that allows the user to obtain photographs of the area under study, either in the presence or absence of light. The obtained spectra are displayed and visualized with the aid of specialized software (OPUS 7) and processed using ORIGIN. In order to reduce noise signals in the spectra, 32 scans were carried out on each piece. The experimental bands were compared with spectra from databases [20].

\section{Raman spectroscopy}

The Raman spectrometer used was an Inspector Raman by Delta-Nu handheld system, equipped with a 785$\mathrm{nm}$ laser with a spectral range from 200 to $2000 \mathrm{~cm}^{-1}$. A removable microscope with LED light and a camera are also included. It was set to work with a resolution of $15 \mathrm{~cm}^{-1}$. The characteristic mineral spectra were obtained usually after $15 \mathrm{~s}$ of measurement on a $50 \mu \mathrm{m}$ spot. However, the NuScope software gives us the capability of adjusting the acquisition time from $1 \mathrm{~s}$ to observe less fluorescence. The peaks were compared with RRUFF databases in order to identify the minerals.

\section{X-ray fluorescence spectroscopy (XRF)}

Portable equipment for the elemental XRF study was the non-destructive X-ray analysis system (SANDRA) developed by our group [21]. It is composed of a Mo X-Ray tube with a Be window, a X-123 Si-PIN detector from Amptek and a collimator of $1.5-\mathrm{mm}$ diameter. Two lasers are manually focused using a camera coupled with the device in order to set the analysis region. The conditions used for the analyses were $0.500 \mathrm{~mA}, 35 \mathrm{kV}$ and the spectra acquisition lasted $90 \mathrm{~s}$ per region. The obtained datasets were processed with the software Amptek PMCA. Subsequently, the semi-quantitative study was performed with the aid of the AXIL software [22-26].

\section{Color measurements (CM)}

The system employed for these measurements was an Ocean Optics USB2000 spectrometer with a 200-900 nm fiber optic spectral range and equipped with a CCD detector and a Vis-NIR fiber optic probe. The obtained measurements of $a^{*}$ (green-red), $b^{*}$ (yellow-blue) from CIE-Lab were processed using ORIGIN [27]. Given the heterogeneity of green tonalities in the pieces, different points were chosen on each object to gather the maximum possible information on color variability.

\section{Results and discussion}

Each artifact was analyzed using FTIR, Raman, XRF, and color measurements $[28,29]$. However, it was not always possible to obtain valuable information from each technique, as for instance in the case with Raman spectra, some minerals may generate a high fluorescence, resulting in a Raman spectrum dominated by this phenomenon. In contrast with the FTIR and XRF results, we were able to pinpoint the different minerals used in the royal burials. 
Nevertheless, in some specific cases, Raman provided useful data for the mineral identification (e.g. muscovite).

In this study we were able to identify a range of different minerals among the greenstones, such jadeite, albite, omphacite, quartz, muscovite and amazonite [30]. Table 1 presents an overview of these minerals: the inventory number assigned for each of the artifacts is noted along with the temple in which it was discovered, the technique used to identify minerals, and the detected elements. Several pieces have a combination of two or more minerals. Below we present details on the mineralogical study by FTIR and Raman for each set of objects from each temple, a discussion of the elemental composition data and finally the color measurement results.

\section{Mineral identification}

(a) Temple of the Skull

The five objects studied from this temple are shown in Figure 2. They consist of a mineral carving, and two necklaces. In the latter we differentiate between the necklace charm and the beads. Their FTIR and Raman spectra are presented in Figures 3 and 4, respectively. All of the objects are composed of both jadeite and albite. The two strong absorption bands observed near 1000 and $1050 \mathrm{~cm}^{-1}$ can be related to the $\mathrm{Si}-\mathrm{O}$ bond stretching vibrations which occur in albite. Also, bands at 600 and $470 \mathrm{~cm}^{-1}$ are attributed to the albite $\mathrm{O}-\mathrm{Si}-\mathrm{O}$ bond angle deformations. As for jadeite, strong bands between 950 and $1100 \mathrm{~cm}^{-1}$ correspond to various $\mathrm{Si}-\mathrm{O}$ vibrational stretching modes and those shown between 425 and $585 \mathrm{~cm}^{-1}$ refer to jadeite $\mathrm{Si}-\mathrm{O}-\mathrm{Si}$ bond angle deformations and $\mathrm{Al}-\mathrm{O}$ vibrations. However, the quantity of albite differs from piece to piece.

One way to differentiate between nephrite and jadeite is the presence of peaks near 756 and $685 \mathrm{~cm}^{-1}$ in the FTIR reference spectrum of nephrite (Figure 3). None of the spectra obtained shows those absorption bands. This correlates with the fact that nephrite has not been found in Mesoamerica and the only known archaeological source of jadeite in that area is the Motagua Valley.

The results are also confirmed by the available Raman data, as presented in Figure 4. Characteristic Raman vibrations of jadeite in reference spectra can be found at 292 and $328 \mathrm{~cm}^{-1}$ ( $\mathrm{Na}-\mathrm{O}$ stretching vibrations), at $375 \mathrm{~cm}^{-1}$ (due to $\mathrm{Al}-\mathrm{O}$ vibrations), at 524, 700 and $779 \mathrm{~cm}^{-1}$ (Si-O bending vibrations) and at 986, 992 and $1040 \mathrm{~cm}^{-1}$ (Si-O stretching vibrations). In the experimental spectra, due to the production of background fluorescence, only the strongest peaks can be matched with the reference spectra, such as those produced by $\mathrm{Al}-\mathrm{O}$ vibrations and bending and stretching $\mathrm{Si}-\mathrm{O}$ vibrations.

The artifact 1761 is one of the necklace beads while piece 1762 is the necklace charm and both are primarily composed of jadeite, with minimal presence of albite in some of the analyzed beads. Similar to the previous case, piece 1763 refers to the set of beads while piece 1764 is the charm. Only jadeite was identified in these two artifacts.

(b) Temple of the Cross

A ring-shaped object, a set of two column-type bars and a pectoral ornament were studied from this temple (Figure 5). The predominant minerals found in these pieces are omphacite, found in the ring-shaped object and the pectoral ornament, and muscovite in the columns.

Due to the molecular similarities between omphacite and jadeite, is it expected that their infrared spectra are very similar [31]. However, FTIR spectroscopy, make it possible to distinguish one from the other. For example, the relative intensity of the jadeite bands between 900 and $1100 \mathrm{~cm}^{-1}$ changes to a less pronounced difference in the case of omphacite. A second difference is the small shift in the signals of spectra between 400 and $700 \mathrm{~cm}^{-1}$, as well as a shoulder or plateau near $880 \mathrm{~cm}^{-1}$ for omphacite. Typical infrared spectra of these artifacts are shown in Figure 6. Here the experimental spectrum obtained is compared with the FTIR reference of jadeite to stress the difference. The twelve pieces corresponding to 14131424 , presumably part of an ornament used in the pectoral area, were identified as composed of omphacite.

On the other hand, the two column-type objects were found to be composed of a combination of minerals where muscovite is present but the other mineral component remains unidentified. The two columns are identified as a muscovite type mineral, with typical IR stretching vibrations for $\mathrm{Si}-\mathrm{O}$ in muscovite that appear near $1030 \mathrm{~cm}^{-1}$ and its bending equivalent at $470 \mathrm{~cm}^{-1}$, $\mathrm{Al}-\mathrm{OH}$ bands that can be seen near $910 \mathrm{~cm}^{-1}$, in-plane vibrations $\mathrm{Si}-\mathrm{O}-\mathrm{Al}$ at $748 \mathrm{~cm}^{-1}$ and $\mathrm{Al}-\mathrm{O}$ stretching vibrations at $825 \mathrm{~cm}^{-1}$. Raman spectra (Figure 7) show $\mathrm{Si}-\mathrm{O}-\mathrm{Si}$ symmetric stretching vibrations around $700 \mathrm{~cm}^{-1}$ and $\mathrm{Al}-\mathrm{O}-\mathrm{Al}$ symmetric stretching vibrations at $410 \mathrm{~cm}^{-1}$.

(c) Temple XVIII

From the Temple XVIII, nine objects were analyzed. These objects consist of two bracelets, five necklaces and two small plaques as shown in Figure 8. Each of the bracelets and necklaces is composed of several beads. In total 235 beads were analyzed among the nine items. The large majority of them were identified as jadeite or omphacite with some albite. Other minerals identified were muscovite, green quartz and amazonite. Their characteristic FTIR spectra are presented in Figures 9 and 10 (see also Additional file 1).

Characteristic infrared vibrations of green quartz are observed between 1080 and $1175 \mathrm{~cm}^{-1}$ due to $\mathrm{Si}-\mathrm{O}$ 
Table 1 List of the pieces analyzed from each temple (ordered chronologically) and results of their mineral characterization. Detected elements were ordered by its X-ray intensity in the XRF spectra

\begin{tabular}{|c|c|c|c|c|}
\hline & Piece & Applied techniques & Mineral identification & Detected elements \\
\hline \multirow[t]{5}{*}{ Temple XVIII-A (A.D. 250-450) } & 1343 & FTIR, XRF & Jadeite/albite & $\mathrm{Fe}, \mathrm{Ca}, \mathrm{Cr}, \mathrm{Si}, \mathrm{Ni}, \mathrm{Zn}, \mathrm{Mn}, \mathrm{Sr}, \mathrm{Ti}$ \\
\hline & & $\mathrm{FTIR}, \mathrm{XRF}$ & Obsidian & $\mathrm{Fe}, \mathrm{K}, \mathrm{Ca}, \mathrm{Si}, \mathrm{Rb}, \mathrm{Sr}, \mathrm{Mn}, \mathrm{Ti}$ \\
\hline & & FTIR, XRF & Calcium carbonate & $\mathrm{Ca}, \mathrm{Sr}$ \\
\hline & 1347 & FTIR, Raman, XRF, CM & Jadeite & $\mathrm{Fe}, \mathrm{Ca}, \mathrm{Si}, \mathrm{Cr}, \mathrm{S}, \mathrm{Ni}, \mathrm{Ti}, \mathrm{Mn}$ \\
\hline & 1348 & XRF & - & $\mathrm{Ca}, \mathrm{Sr}, \mathrm{Fe}$ \\
\hline \multirow[t]{6}{*}{ Temple of the Cross (A.D. 300-600) } & 1410 & FTIR, Raman, CM & Omphacite & - \\
\hline & 1411 & FTIR, Raman, XRF, CM & Muscovite & $\mathrm{K}, \mathrm{Fe}, \mathrm{Sr}, \mathrm{Ti}, \mathrm{V}, \mathrm{Si}, \mathrm{Rb}, \mathrm{Ca}, \mathrm{Cr}$ \\
\hline & & FTIR, Raman, XRF, CM & Unidentified & $\mathrm{Ca}, \mathrm{Fe}, \mathrm{Sr}, \mathrm{K}, \mathrm{Si}, \mathrm{Ti}, \mathrm{V}, \mathrm{Rb}$ \\
\hline & 1412 & FTIR, Raman, XRF, CM & Muscovite & $\mathrm{K}, \mathrm{Fe}, \mathrm{Sr}, \mathrm{Ti}, \mathrm{V}, \mathrm{Si}, \mathrm{Rb}, \mathrm{Ca}, \mathrm{Cr}$ \\
\hline & & FTIR, Raman, XRF, CM & Unidentified & $\mathrm{Ca}, \mathrm{Fe}, \mathrm{Sr}, \mathrm{K}, \mathrm{Pb}, \mathrm{Si}, \mathrm{Ti}, \mathrm{V}$ \\
\hline & $1413-1424$ & FTIR, Raman, XRF, CM & Omphacite & $\mathrm{Fe}, \mathrm{Ca}, \mathrm{Sr}, \mathrm{Si}, \mathrm{Cr}, \mathrm{Mn}, \mathrm{Ni}, \mathrm{Ti}, \mathrm{S}$ \\
\hline \multirow[t]{7}{*}{ Temple of the Skull (A.D. 700-770) } & 1344 & FTIR, XRF, CM & Jadeite & $\mathrm{Fe}, \mathrm{Ca}, \mathrm{Cr}, \mathrm{Si}, \mathrm{Sr}, \mathrm{Ga}, \mathrm{Mn}, \mathrm{Ti}$ \\
\hline & & FTIR, XRF, CM & Albite & $\mathrm{Fe}, \mathrm{Ca}, \mathrm{Cr}, \mathrm{Hg}, \mathrm{Si}, \mathrm{Sr}, \mathrm{Zn}, \mathrm{Mn}, \mathrm{Ni}, \mathrm{S}, \mathrm{Ti}$ \\
\hline & 1761 & FTIR, Raman, XRF, CM & Albite & $\mathrm{Fe}, \mathrm{Ca}, \mathrm{Si}, \mathrm{Mn}, \mathrm{Zn}, \mathrm{Cr}$ \\
\hline & & FTIR, Raman, XRF, CM & Jadeite & $\mathrm{Fe}, \mathrm{Ca}$, Si, Sr, Mn, Ga, Cr, Ni, V, S \\
\hline & 1762 & FTIR, XRF, CM & Jadeite & $\mathrm{Fe}, \mathrm{Ca}, \mathrm{Sr}, \mathrm{Cr}, \mathrm{Si}, \mathrm{Ga}$ \\
\hline & 1763 & FTIR, Raman, XRF, CM & Jadeite & $\mathrm{Fe}, \mathrm{Ca}, \mathrm{Si}, \mathrm{Sr}, \mathrm{Ni}, \mathrm{Cr}, \mathrm{V}, \mathrm{Mn}$ \\
\hline & 1764 & FTIR, Raman, XRF, CM & Jadeite & $\mathrm{Fe}, \mathrm{Ca}, \mathrm{Si}, \mathrm{Sr}, \mathrm{Cr}, \mathrm{Mn}, \mathrm{S}$ \\
\hline \multirow[t]{27}{*}{ Temple XVIII (A.D. 600-850) } & 1765 & FTIR, Raman, XRF, CM & Jadeite & $\mathrm{Fe}, \mathrm{Ca}, \mathrm{Cr}, \mathrm{Mn}, \mathrm{Si}, \mathrm{Ni}, \mathrm{Sr}$ \\
\hline & & FTIR, Raman, XRF, CM & Muscovite & $\mathrm{K}, \mathrm{Fe}, \mathrm{Sr}, \mathrm{Ti}, \mathrm{Ca}, \mathrm{Cr}, \mathrm{Rb}, \mathrm{Zn}, \mathrm{Si}, \mathrm{Cu}, \mathrm{Ni}$ \\
\hline & & FTIR, Raman, XRF, CM & Jadeite/albite & $\mathrm{Fe}, \mathrm{Ca}, \mathrm{Si}, \mathrm{Mn}, \mathrm{Ni}, \mathrm{Ti}, \mathrm{K}, \mathrm{Cr}$ \\
\hline & & FTIR, Raman, XRF, CM & Omphacite & $\mathrm{Fe}, \mathrm{Ca}, \mathrm{Cr}, \mathrm{K}, \mathrm{Ni}, \mathrm{Si}, \mathrm{Mn}, \mathrm{Sr}$ \\
\hline & & FTIR, Raman, XRF, CM & Quartz & $\mathrm{Ca}, \mathrm{Cr}, \mathrm{Fe}, \mathrm{Si}, \mathrm{Zn}, \mathrm{Ni}, \mathrm{Rb}, \mathrm{K}, \mathrm{Cu}, \mathrm{Mn}$ \\
\hline & 2433 & FTIR, Raman, XRF, CM & Jadeite & $\mathrm{Fe}, \mathrm{Ca}, \mathrm{Ga}, \mathrm{Ni}, \mathrm{Si}, \mathrm{Cr}, \mathrm{Mn}, \mathrm{Ti}$ \\
\hline & & FTIR, Raman, XRF, CM & Omphacite & $\mathrm{Ca}, \mathrm{Fe}, \mathrm{Ni}, \mathrm{Cr}, \mathrm{Sr}, \mathrm{Si}, \mathrm{Mn}, \mathrm{Ga}$ \\
\hline & & FTIR, Raman, XRF, CM & Albite & $\mathrm{Fe}, \mathrm{Ca}, \mathrm{Sr}, \mathrm{Si}, \mathrm{Cr}, \mathrm{Ga}, \mathrm{Zn}, \mathrm{Ni}, \mathrm{Mn}, \mathrm{K}, \mathrm{S}, \mathrm{V}$ \\
\hline & 2439 & FTIR, XRF & Jadeite & $\mathrm{Fe}, \mathrm{Ca}, \mathrm{Si}, \mathrm{Cr}, \mathrm{Mn}, \mathrm{Ga}, \mathrm{Sr}, \mathrm{Ti}, \mathrm{Ni}$ \\
\hline & & FTIR, XRF & Jadeite/albite & $\mathrm{Fe}, \mathrm{Ca}, \mathrm{Si}, \mathrm{Sr}, \mathrm{S}, \mathrm{Mn}, \mathrm{Ti}, \mathrm{Cr}$ \\
\hline & 2440 & FTIR, Raman, XRF, CM & Jadeite/albite & $\mathrm{Fe}, \mathrm{Ca}, \mathrm{Si}, \mathrm{Sr}, \mathrm{S}, \mathrm{Mn}, \mathrm{Ti}, \mathrm{Cr}$ \\
\hline & & FTIR, Raman, XRF, CM & Amazonite/albite & $\mathrm{Rb}, \mathrm{K}, \mathrm{Ca}, \mathrm{Cu}, \mathrm{Fe}, \mathrm{Si}, \mathrm{Hg}, \mathrm{Ti}$ \\
\hline & & FTIR, Raman, XRF, CM & Albite & $\mathrm{Fe}, \mathrm{Ca}, \mathrm{Si}, \mathrm{Sr}, \mathrm{Cu}, \mathrm{K}, \mathrm{Mn}, \mathrm{Ti}$ \\
\hline & & FTIR, Raman, XRF, CM & Omphacite & $\mathrm{Ca}, \mathrm{Fe}, \mathrm{Mn}, \mathrm{Sr}, \mathrm{Si}, \mathrm{Cr}, \mathrm{K}, \mathrm{Ti}$ \\
\hline & 2441 & FTIR, XRF & Jadeite/albite & $\mathrm{Fe}, \mathrm{Ca}, \mathrm{Cr}, \mathrm{Sr}, \mathrm{Ni}, \mathrm{Cu}, \mathrm{Mn}, \mathrm{Si}, \mathrm{Ti}, \mathrm{K}$ \\
\hline & & $\mathrm{FTIR}, \mathrm{XRF}$ & Jadeite & $\mathrm{Fe}, \mathrm{Ca}, \mathrm{Hg}, \mathrm{Cr}, \mathrm{Zn}, \mathrm{Si}, \mathrm{Mn}, \mathrm{Ni}, \mathrm{K}, \mathrm{Ti}$ \\
\hline & 2442 & FTIR, Raman, XRF & Amazonite & $\mathrm{Rb}, \mathrm{K}, \mathrm{Fe}, \mathrm{Ca}, \mathrm{Si}, \mathrm{Pb}, \mathrm{Ga}$ \\
\hline & & FTIR, Raman, XRF & Jadeite & $\mathrm{Fe}, \mathrm{Ca}, \mathrm{Hg}, \mathrm{Cr}, \mathrm{Ti}, \mathrm{Si}, \mathrm{Mn}, \mathrm{K}$ \\
\hline & & FTIR, Raman, XRF & Omphacite & $\mathrm{Ca}, \mathrm{Fe}, \mathrm{Ni}, \mathrm{Cr}, \mathrm{Sr}, \mathrm{Si}, \mathrm{Mn}, \mathrm{Ti}, \mathrm{K}$ \\
\hline & 2443 & FTIR, XRF & Albite & $\mathrm{Sr}, \mathrm{Ca}, \mathrm{Fe}, \mathrm{Ni}, \mathrm{Si}, \mathrm{Cr}, \mathrm{Hg}, \mathrm{Mn}$ \\
\hline & & $\mathrm{FTIR}, \mathrm{XRF}$ & Jadeite & $\mathrm{Fe}, \mathrm{Ca}, \mathrm{Sr}, \mathrm{Si}, \mathrm{Ni}, \mathrm{Mn}, \mathrm{Hg}, \mathrm{Cr}, \mathrm{Ti}$ \\
\hline & & FTIR, XRF & Omphacite & $\mathrm{Fe}, \mathrm{Ca}, \mathrm{Sr}, \mathrm{Si}, \mathrm{Mn}, \mathrm{Zr}, \mathrm{Cr}, \mathrm{Ni}$ \\
\hline & & FTIR, XRF & Quartz & $\mathrm{Fe}, \mathrm{Cr}, \mathrm{Ca}, \mathrm{Si}, \mathrm{Hg}, \mathrm{Ni}, \mathrm{K}, \mathrm{Mn}, \mathrm{S}$ \\
\hline & 2671 & FTIR, XRF & Amazonite & $\mathrm{Rb}, \mathrm{K}, \mathrm{Ga}, \mathrm{Pb}, \mathrm{Si}, \mathrm{Ca}, \mathrm{Se}, \mathrm{Fe}$ \\
\hline & & $\mathrm{FTIR}, \mathrm{XRF}$ & Jadeite & $\mathrm{Fe}, \mathrm{Ca}, \mathrm{Si}, \mathrm{Cu}, \mathrm{Mn}, \mathrm{Cr}, \mathrm{Ni}, \mathrm{S}, \mathrm{Ti}$ \\
\hline & 2933 & FTIR, Raman, XRF, CM & Albite & $\mathrm{Zn}, \mathrm{Si}, \mathrm{Sr}, \mathrm{Ca}, \mathrm{Fe}$ \\
\hline & & FTIR, Raman, XRF, CM & Jadeite & $\mathrm{Fe}, \mathrm{Ca}, \mathrm{Rb}, \mathrm{Si}, \mathrm{Cr}, \mathrm{Mn}$ \\
\hline
\end{tabular}



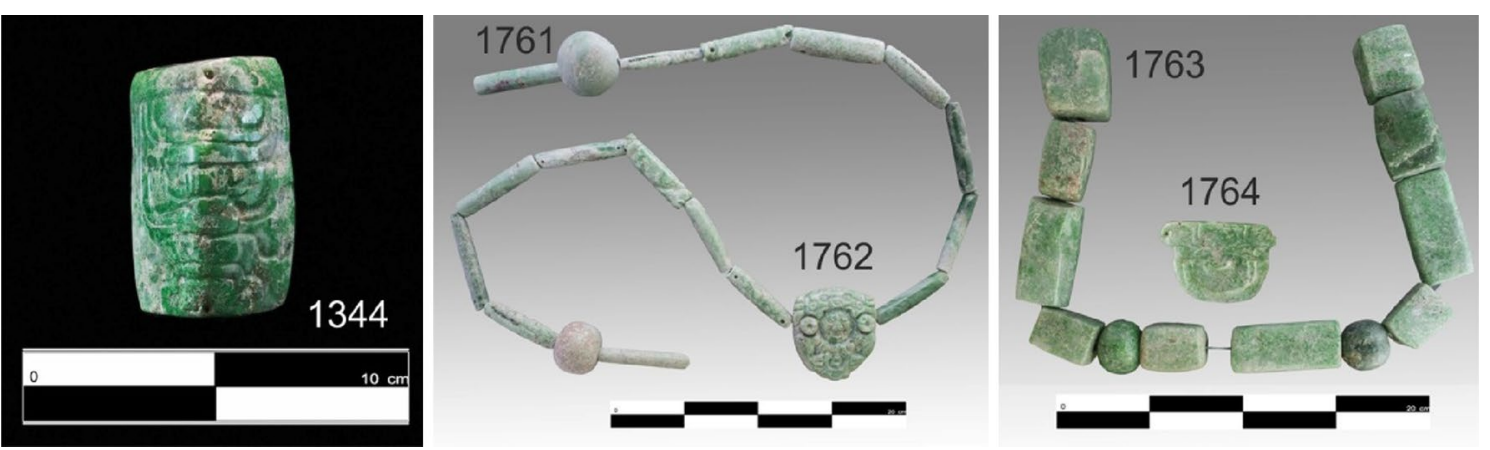

Figure 2 Mineral carving and two necklaces from the Temple of the Skull (A.D. 700-770).

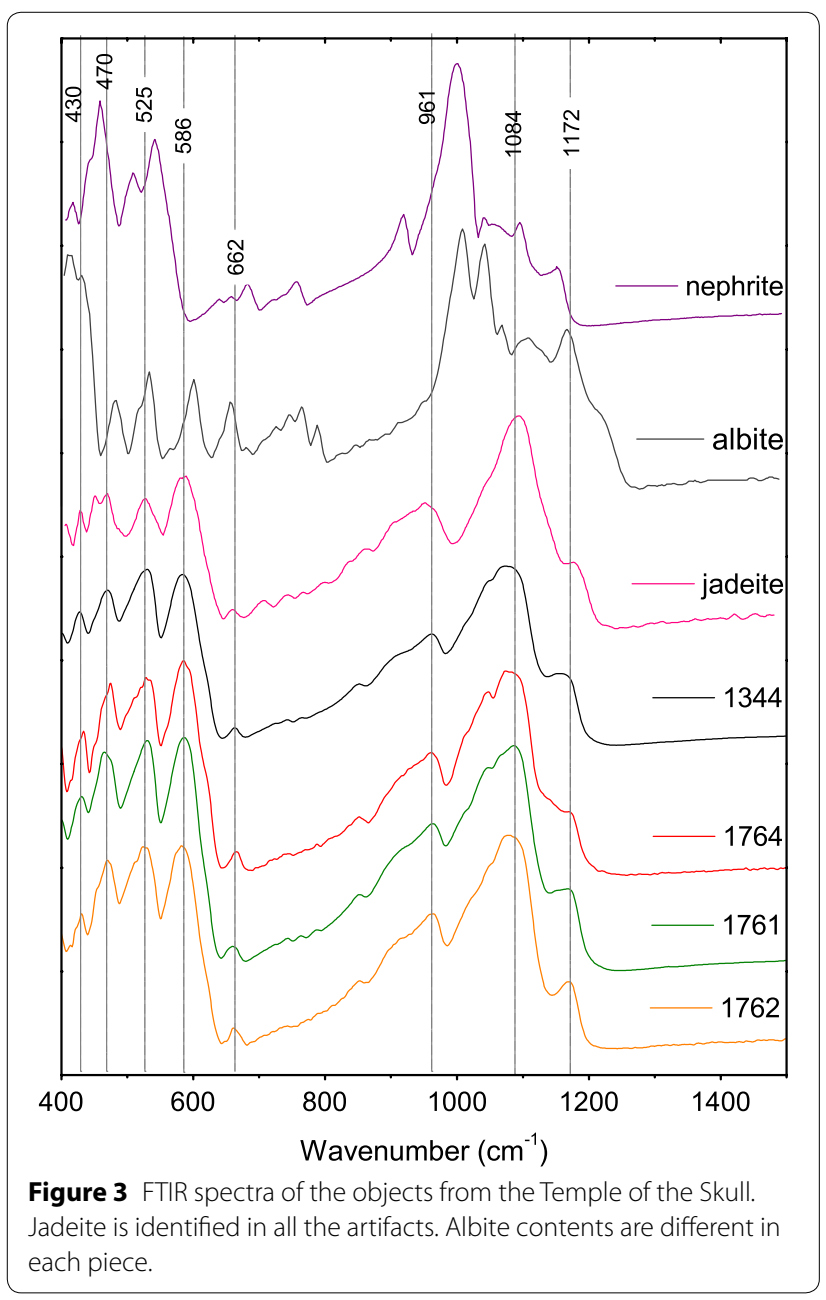

asymmetric stretching vibrations; $\mathrm{Si}-\mathrm{O}$ stretching vibrations near 780 and $800 \mathrm{~cm}^{-1}$; $\mathrm{Si}-\mathrm{O}$ asymmetric bending vibrations at $474 \mathrm{~cm}^{-1}$ and symmetric vibrations of the same bond at $695 \mathrm{~cm}^{-1}$. Its Raman vibrations include peaks near $450 \mathrm{~cm}^{-1}$ due to $\mathrm{Si}-\mathrm{O}$ symmetric stretching

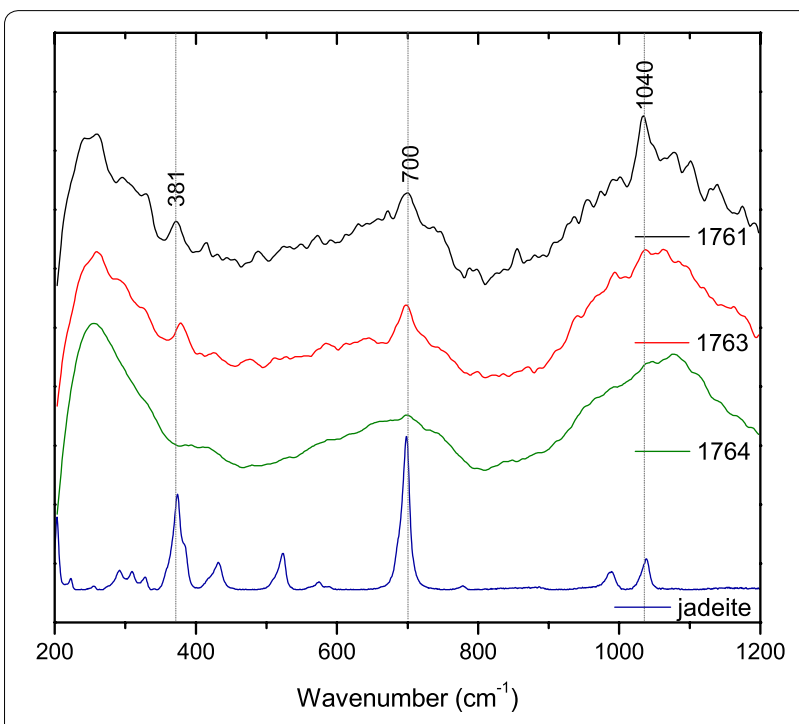

Figure 4 Raman spectra of the pieces from the Temple of the Skull. Jadeite identification agrees FTIR results.

vibrations and bending vibrational modes between 800 and $1100 \mathrm{~cm}^{-1}$ of the $\mathrm{Si}-\mathrm{O}-\mathrm{Si}$ bond. Amazonite, on the other hand is a feldspar whose characteristic peaks can be observed between 475 and $515 \mathrm{~cm}^{-1}$ ( $\mathrm{Si}-\mathrm{O}$ bond vibrations and $\mathrm{Si}-\mathrm{O}-\mathrm{Si}$ or $\mathrm{Si}-\mathrm{O}-\mathrm{Al})$. The peak shown near $252 \mathrm{~cm}^{-1}$ relates to lattice vibrational modes of the described mineral.

Piece 2433, after FTIR analysis, was found to have jadeite, omphacite and albite in its composition. Raman studies were helpful to confirm the presence of these minerals, as well as to identify amazonite using reference spectra. The artifact 2439 revealed the presence of a combination of jadeite and albite, as it can be concluded from an overlapping of characteristic peaks for each one of the involved minerals in the infrared and Raman corresponding spectra. In the beads of the bracelet 2440 , a combination of amazonite/albite, jadeite/albite, 

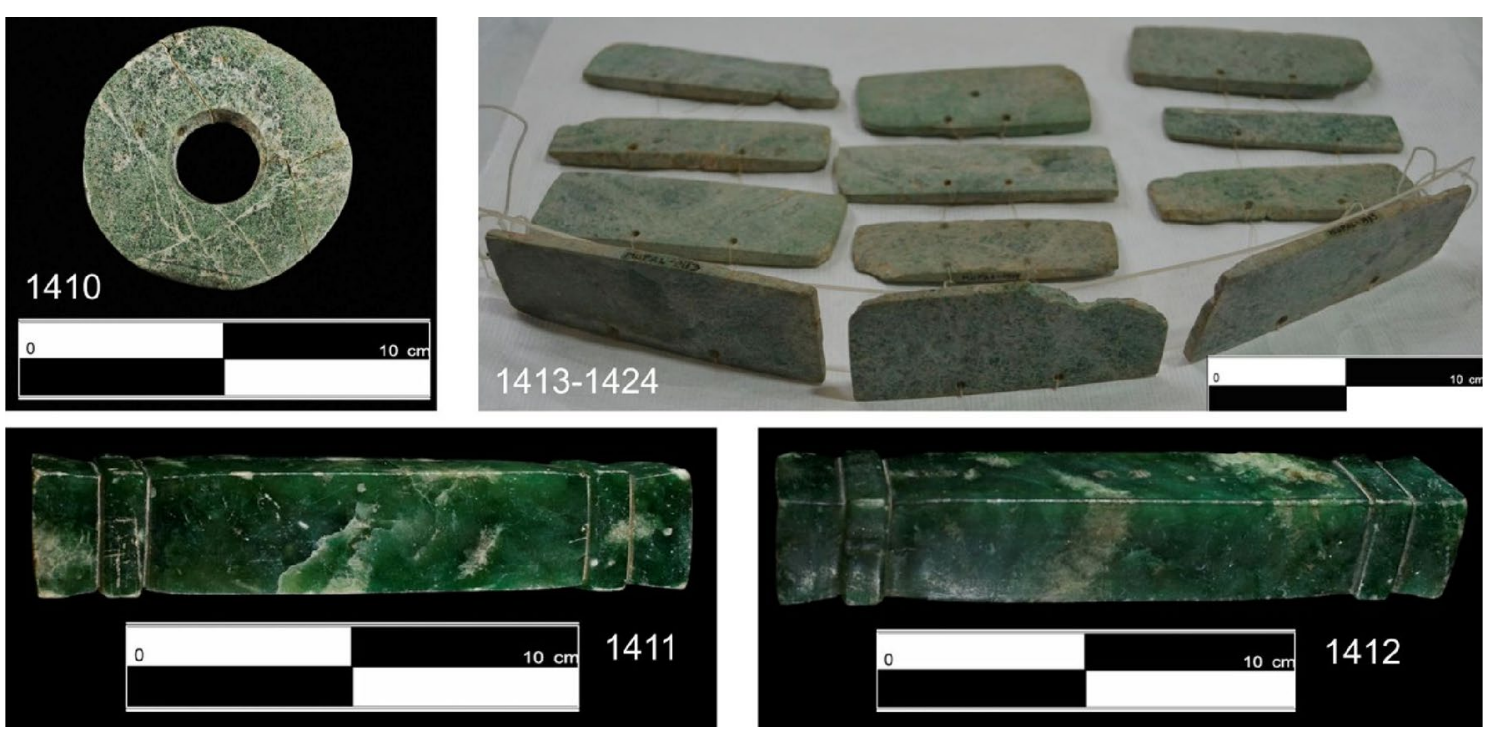

Figure 5 Ring-shaped object, a set of two column-type bars and a pectoral ornament discovered in the Temple of the Cross (A.D. 300-600)

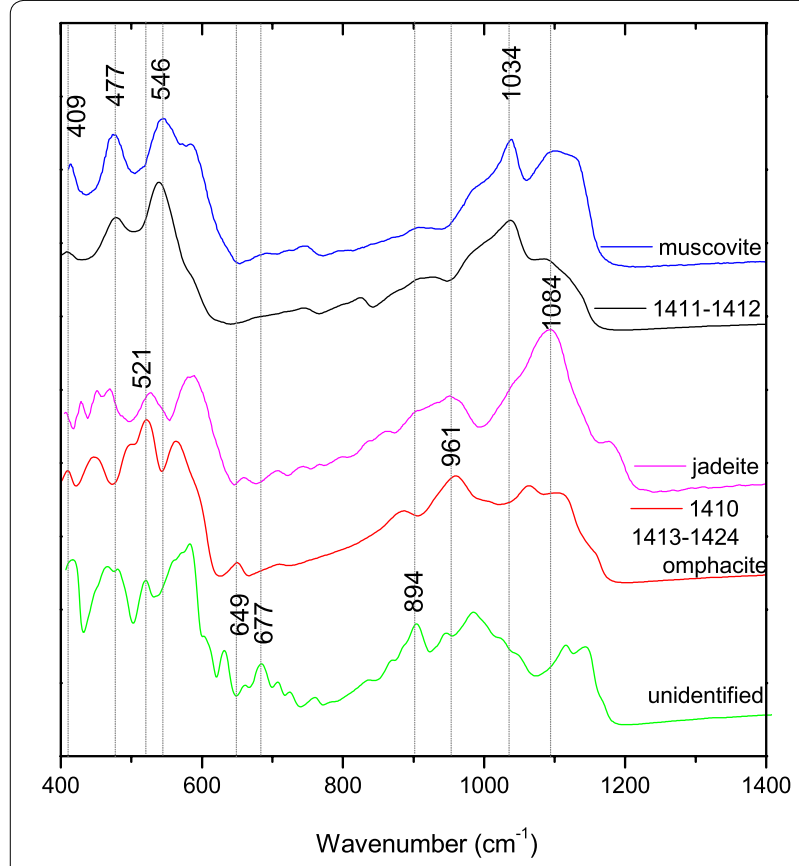

Figure 6 Typical FTIR spectra of pieces from the Temple of the Cross. Muscovite and omphacite are identified.

omphacite and albite were identified. Jadeite and jadeite/albite were confirmed in piece 2441 while amazonite, jadeite and omphacite were detected in the beads of the necklace 2442; also jadeite, omphacite, quartz and albite were found in piece 2443 whereas amazonite and jadeite were identified in the beads of artifact 2671. Jadeite and

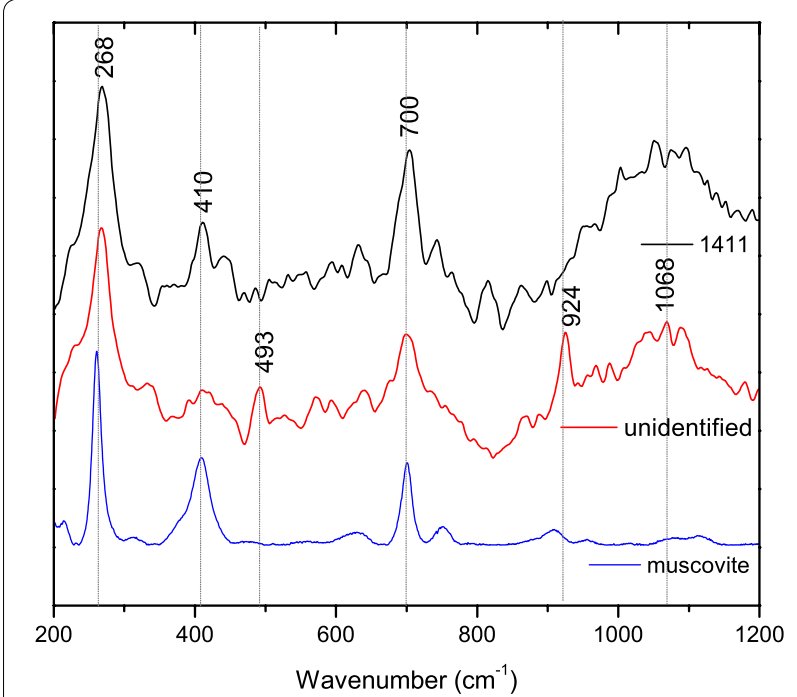

Figure 7 Raman spectra of pieces from the Temple of the Cross. Muscovite peaks are observed.

albite are the minerals that constitute the small plaque 2933.

The variety of minerals clearly increased after A.D. 600, probably due to Palenque's growth and its consolidation as a ruler city in northern Chiapas area and the expansion of its trade routes.

(d) Temple XVIII-A

In total, three types of artifacts from the earlier Temple XVIII-A were studied. These included a set of two earpieces, a set of three waist ornaments, and a mask 


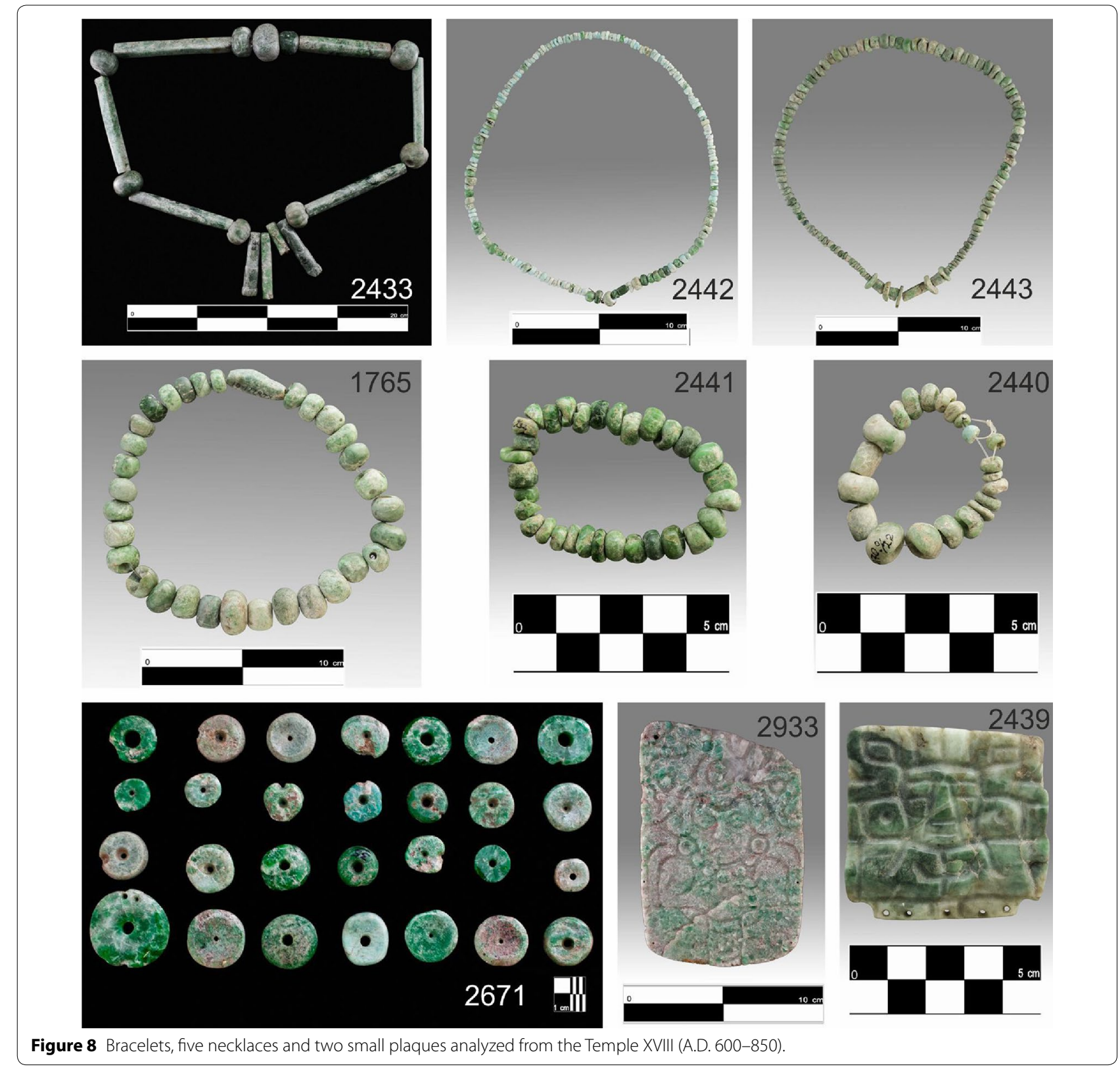

(Figure 11). These objects correspond to the oldest tomb discovered in an elite building at Palenque.

Apart from jadeite and albite in the majority of the mask fragments, obsidian and a shell-like material were found in the irises and the white of the eyes, respectively. The earpieces are pure jadeite artifacts and the waist ornament is made of a calcium carbonate as supported by the high amount of Ca detected in the XRF analyses (Figures 12, 13).

\section{Elemental characterization}

With the aid of XRF, the elemental composition of the objects was identified after comparison of the experimental spectra with the values for the $\mathrm{K}$ and $\mathrm{L}$ emissions (keV)-see Additional file 1. All the elements found correspond to the chemical composition of the identified minerals, including trace elements that may be useful for identification of mineral deposits (Table 1).

$\mathrm{XRF}$ is helpful for tracking the origin of a certain mineral by taking into consideration its elemental composition. In this sense, a factor analysis approach was followed to facilitate the identification of patterns and relationships between the objects studied [32].

The intensity of the signals obtained by XRF was used for the quantification of the elements that constitute the 

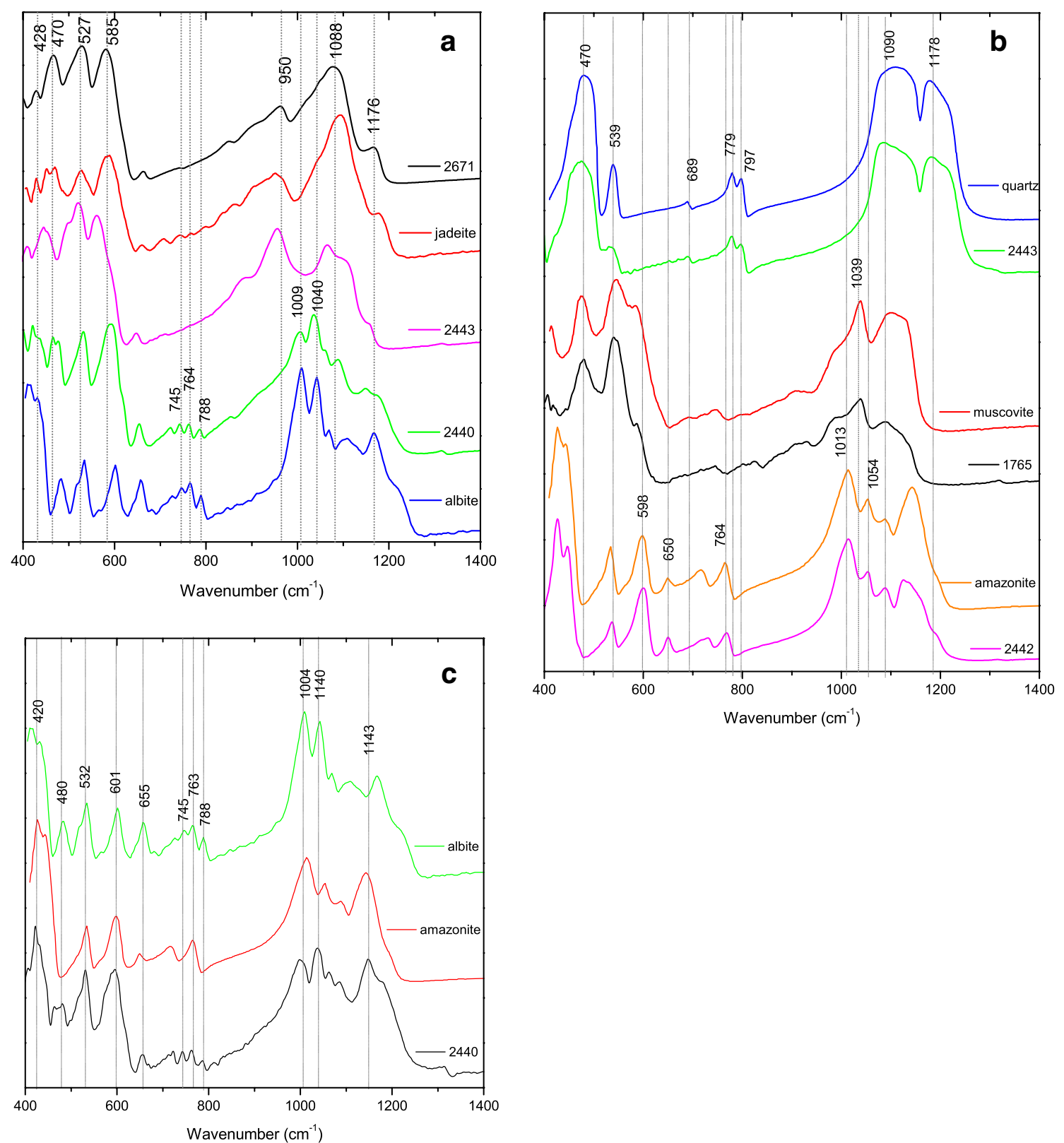

Figure 9 FTIR spectra of $\mathbf{a}$ albite/jadeite, $\mathbf{b}$ quartz, amazonite, muscovite and $\mathbf{c}$ albite/amazonite obtained from the pieces found in the Temple $\mathrm{XVIII.}$

archaeological object. This elemental composition can be used to infer the most probable origin of raw stone materials when it is compared with the elemental composition of the deposit ore. This is feasible for the same type of mineral, so that it was possible to analyze and to interpret the variation in the proportions of the elements in each piece, to identify those with a similar composition and to compare it with the composition of the known deposits of jadeite.
In order to obtain statistically reliable results, the ornaments containing several distinct pieces, such as necklaces and bracelets with many beads, were taken into consideration for this type of analysis. These pieces correspond to objects from Temple XVIII, specifically: 1765 , 2433, 2440, 2441, 2442, 2443 and 2671. Furthermore, the mask 1343 of the Temple XVIII-A was analyzed too, due to its importance This mask is the earliest one discovered in Palenque. 


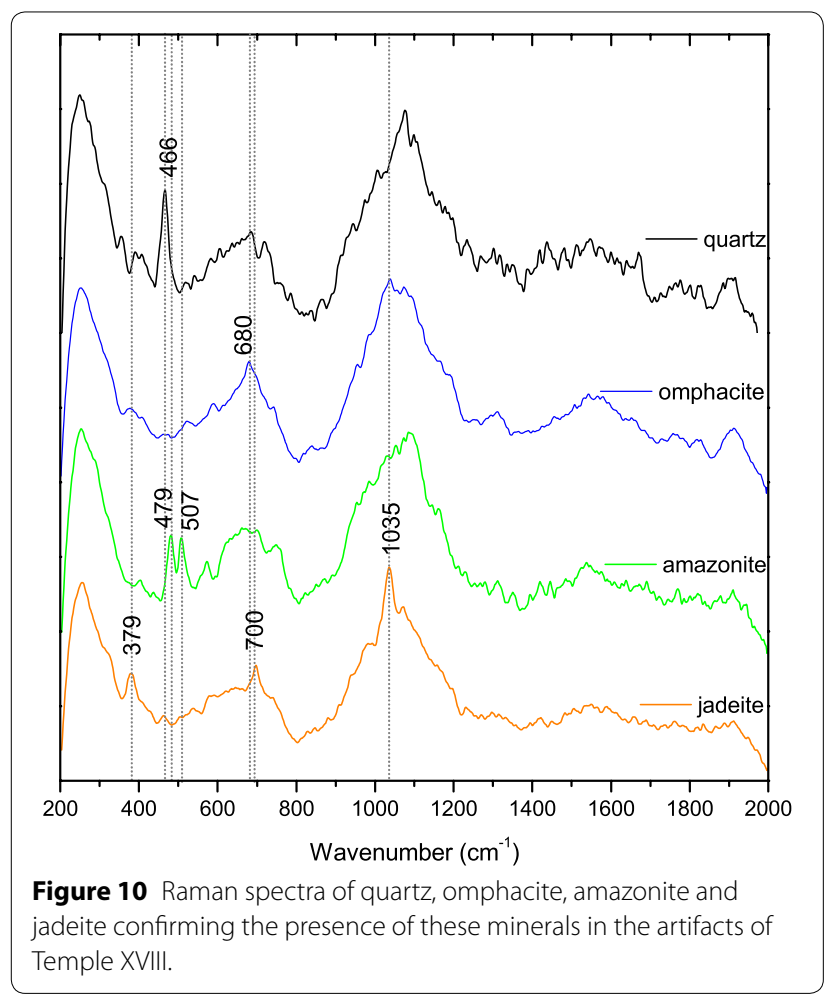

Two Guatemalan jadeite references, one coming from The Motagua Valley $(\mathrm{M})$ and the other one from Verapaz (V), were compared to the experimental elemental composition obtained for each one of the ornaments, in order to infer their origins. The beads that could not be identified using the molecular spectroscopic techniques are called unidentified; however, they were integrated into this analysis due to the similarity in their chemical composition with the jadeite minerals. In Figure 14, we observed three groups of objects separated by their distinct chemical compositions. This might lead to the conclusion that not all of the beads come from the same source. One of the groups fits with the Motagua reference (2) and the other one with Verapaz reference (1), so we can assume the material used for the beads within those groups originated at the Motagua and Verapaz sources, respectively.

Besides, as we can notice, most of the tesserae corresponding to the mask of the Temple XVIII-A (1343) fit with the group number 3 , so we can infer that these actual identified deposits were possibly exploited during the earlier period A.D. 250-450 of Palenque, because few objects correspond to Verapaz and Motagua beds. Later in the period A.D. 600-850, Motagua and Verapaz were the main deposit minerals used to manufacture the ornaments with greenstones, since most of the studied objects correspond to group 1 and 2 . The expansion of exchange routes and the access to more pieces from these sources during the late Classic may be related to Palenque's growth due to the reign of Pakal in this period.

\section{Color measurements}

These measurements $(\mathrm{CM})$ were carried out to obtain valuable information concerning the tonalities of the
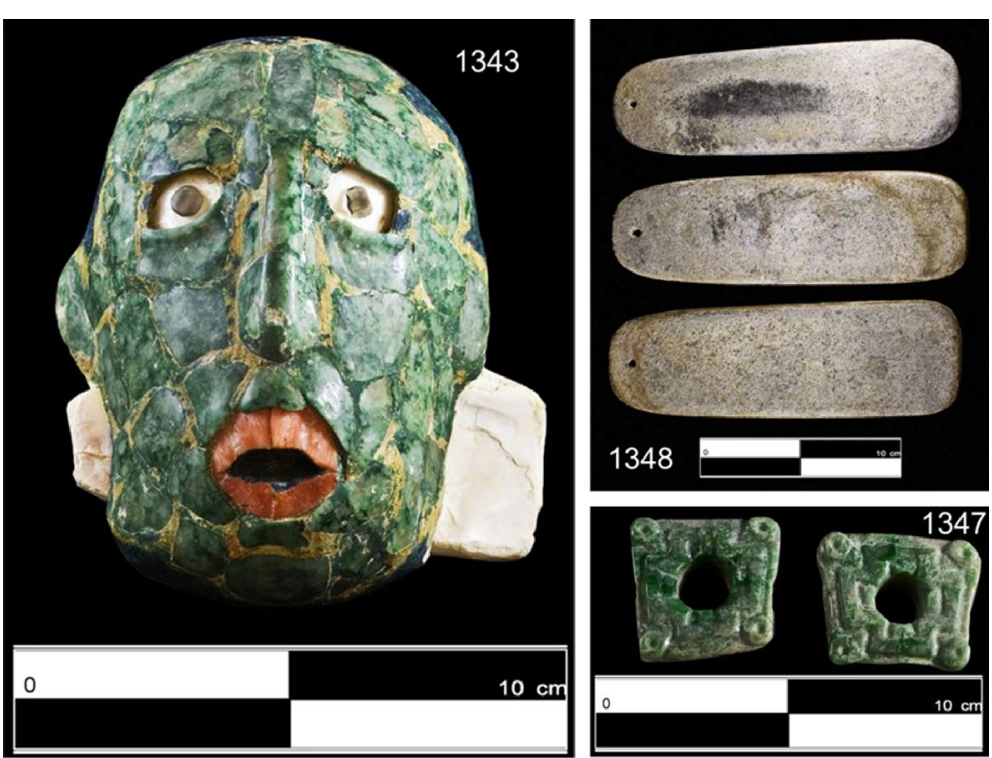

Figure 11 Mask, two earpieces, a set of three waist ornament from the Temple XVIII-A (A.D. 250-450). This mask is the earliest one discovered in an elite tomb in Palenque. 

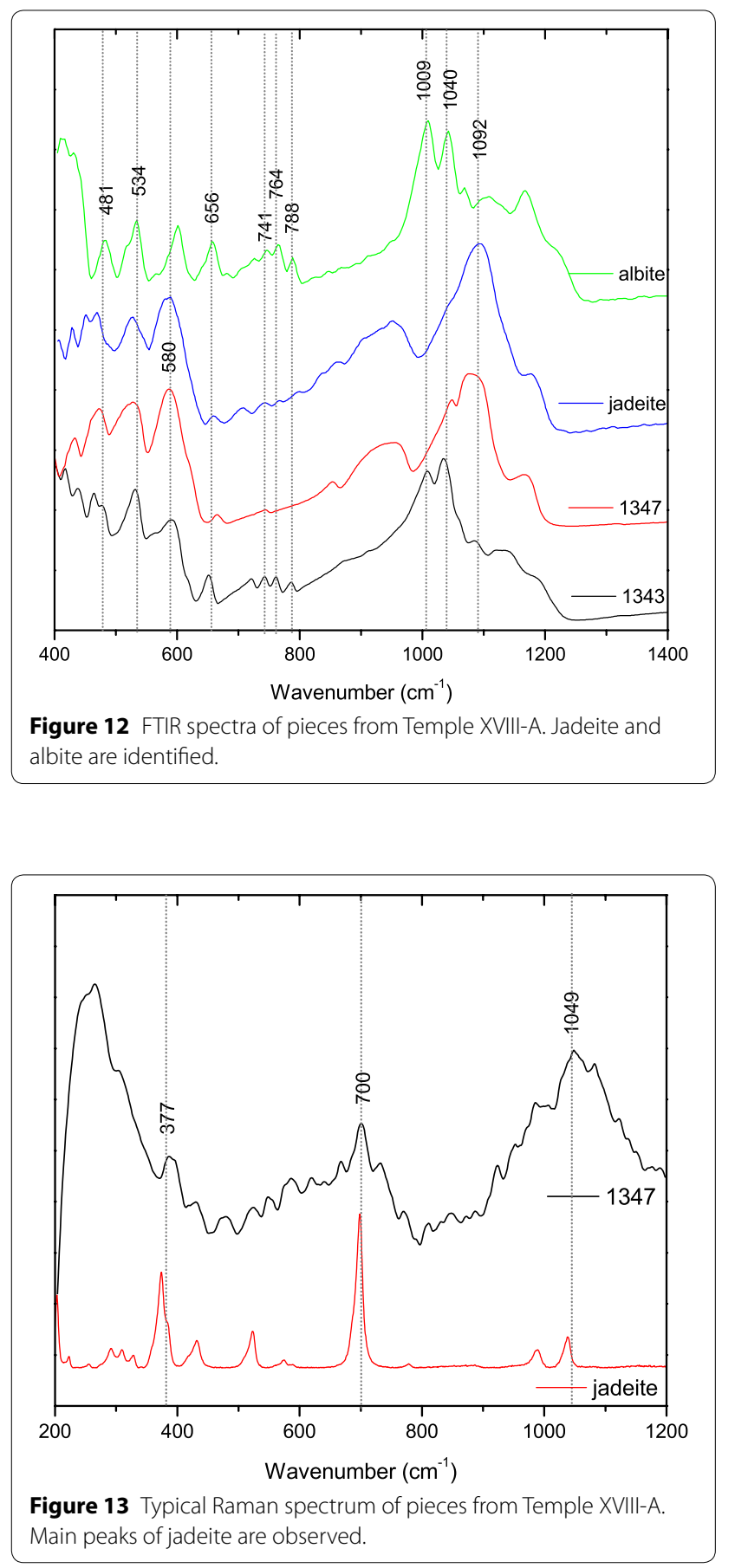

different artifacts [33]. Although it is likely that different greenstones were selected to match the color of the rest of the objects chosen as offerings for the specific temple, it can be seen from Figure 15 that there is considerable color dispersion. More than a religious or social explanation, this color dispersion reflects the natural heterogeneity of the minerals employed in the manufacture of the distinct Mayan ornaments. The color measurements show that a higher data dispersion occurs in Temples of the Skull and XVIII, whereas the dispersion is reduced in the Temple of the Cross and XVIII-A, the older constructions. A possible explanation might be that the greenstones found in these last two temples might have been more carefully selected because of the importance of these buildings, regardless of the natural heterogeneity of the stones mentioned before. Another explanation is the increase in the availability of greenstone and stone materials after A.D. 600 following the expansion trade routes and the up growth of Palenque.

\section{Conclusions}

Since the green color was sacred to the Mayan civilization due to its life-giving connotation, greenstones were highly valued. Their use in funerary offerings, rituals and royal ornaments is well documented. The use of Fourier transform infrared and Raman spectroscopies, X-ray fluorescence and color measurements enabled us to implement a holistic suite of methods to identify and classify the different minerals used in burial offerings dating from the Classic period (200-900 A.D.) found in the Mayan Temples of the Skull, the Cross, XVIII and XVIII-A, located in the city of Palenque, Chiapas, Mexico.

FTIR and Raman spectroscopies proved to be useful techniques for the identification of the mineral composition of these archaeological materials, although the latter one showed some limitations due to the presence of non-desired background fluorescence using a $785 \mathrm{~nm}$ laser. The combined use of these spectroscopic techniques supplies satisfactory information about the minerals employed in the manufacture of offerings and ornaments. Although jadeite was particularly valued and treasured by this civilization, a variety of green minerals such as omphacite, quartz, muscovite and albite were identified in the various ornaments studied. Even amazonite, a blue-greenish mineral, was encountered among the artifacts.

XRF was successfully employed to obtain the elemental analyses of the objects. A statistical study was carried out to track the most probable provenance of the beads and tesserae using the relative intensities of characteristic X-rays resulting in the identification of three different mineral ores exploiting during the period 250-850 A.D: an unidentified deposit used earlier during the period 250-450 A.D., and Motagua and Verapaz deposits ores for the later period between 600 and 850 A.D.

In addition, colorimetric studies provided reliable information on the various green tonalities of the analyzed objects. It was observed that, even among ornaments belonging to the same temple, not all pieces have the same mineral composition or the same color. In fact, the pieces exhibit considerable color disparity as well as 


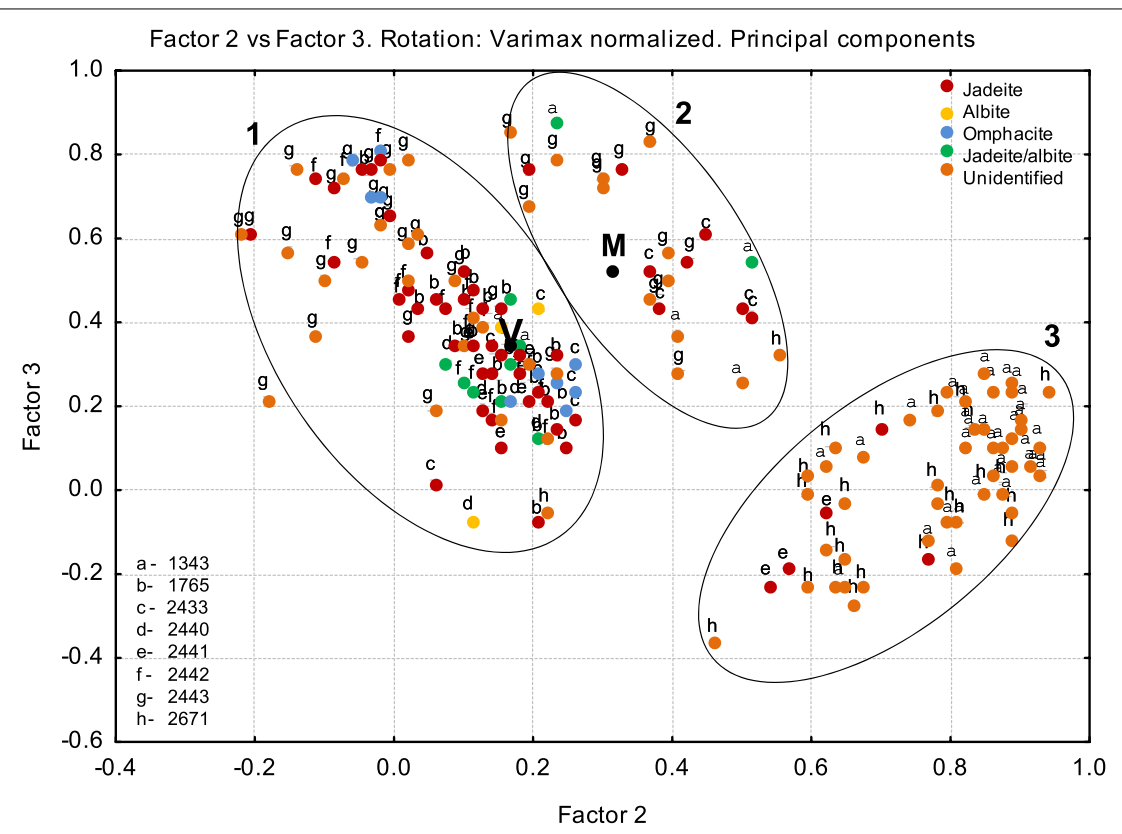

Figure 14 Factor analysis of pieces of the Temple XVIII and the mask of the Temple XVIII-A. Three different groups corresponding to three different jadeite sources are formed. Group 3 is related to an unidentified bed.

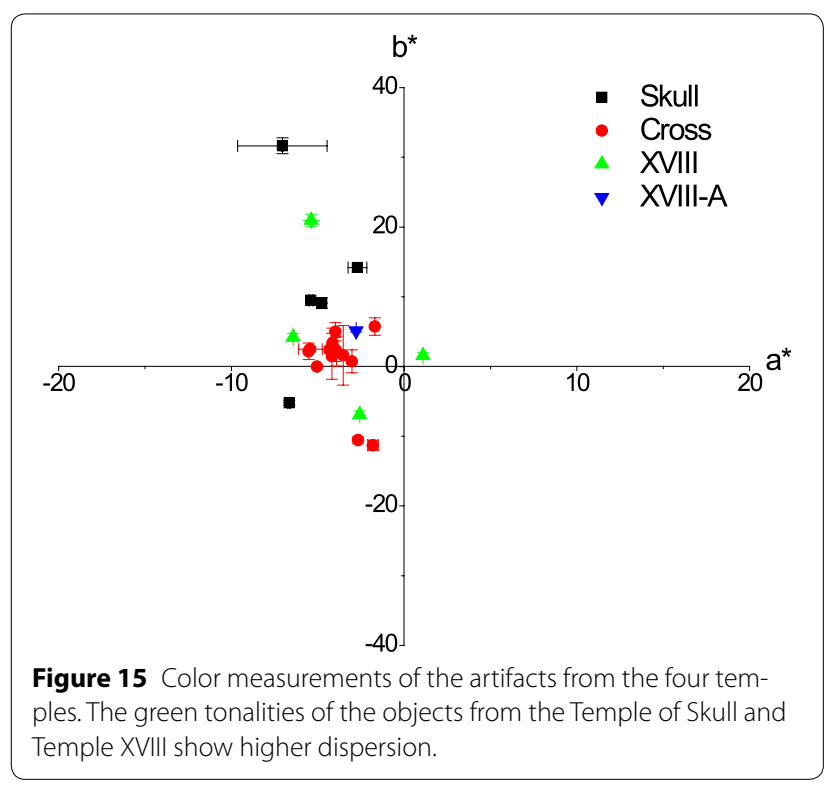

different mineral compositions. Although this could be concluded at first glance given the heterogeneity of their tonalities, it is important to mention that special care must have been taken in the selection of minerals and their tonalities so that the offerings and artifacts placed in one same temple were similar between them.

The increase of available greenstone minerals and access to their sources after A.D. 600 may be related to the growth of Palenque under the ruler Pakal and the consolidation of his dynasty. Palenque, as a pole of power in the northern area of Chiapas, expanded its exchange routes over time and thus its access to objects and materials from other locations.

\section{Additional file}

Additional file 1: Comparison between FTIR spectra of the artifacts from Temple XVIII and mineral reference spectra. XRF spectra correspond to pieces from the four temples.

\section{Abbreviations}

XRF: X-ray fluorescence; FTIR: Fourier transform infrared spectroscopy; SANDRA: Sistema de Análisis No Destructivo por Rayos X or system for nondestructive analysis using X-rays; CM: color measurements.

\section{Authors' contributions}

AADR: collaborated during the experimental measurements, worked on data analyses and interpretation of all of the techniques used, also co-wrote this paper. JLRS: coordinated the study, supervised of the experimental work in Palenque Museum, reviewed data interpretation and co-wrote this paper. PC: performed FTIR, participated in the data interpretation and reviewed the paper. MMO: performed XRF and participated in the data interpretation. ECG: performed Raman and participated in the data interpretation. MMR: performed color measurements. MCG, SGC: collaborated with Palenque's archaeological information and provided access to the archaeological objects and images and data related to the artifacts. All authors read and approved the final manuscript.

\section{Author details}

${ }^{1}$ Instituto de Fisica, Universidad Nacional Autónoma de México, Circuito de la Investigación Científica s/n, Ciudad Universitaria, C.P. 04510 Mexico City, Mexico. ${ }^{2}$ Centro de Investigación en Corrosión, Universidad Autónoma de Campeche, Av. Agustín Melgar S/N entre Calle 20 y Juan de la Barrera, Buenavista, C.P. 24039 Campeche, Mexico. ${ }^{3}$ Dirección de Registro Público de Monumentos y Sitios Arqueológicos, Instituto Nacional de Antropologia e Historia, Victoria 110 Copilco El Bajo, C.P. 04340 Mexico City, Mexico. 


\section{Acknowledgements}

This research has been supported by the projects CONACyT Mexico 131944 MOVIL II, PAPIIT UNAM IN402813 ANDREAH II and ICYTDF PICCO 10-57. PC is grateful for financial support via a DGAPA/UNAM scholarship. The authors are very grateful for the collaboration of Arglga. Sabrina García and Dra. Marta Cuevas of the Dirección de Registro Público de Monumentos y Zonas Arqueológicas of Instituto Nacional de Antropologia e Historia of Mexico and the participation of personal from Palenque's Site Museum. AADR is also very grateful with Dra. Carolina Gutierrez Neira for her collaboration and discussion of data.

\section{Compliance with ethical guidelines}

\section{Competing interests}

The authors declare that they have no competing interests.

Received: 3 December 2014 Accepted: 28 May 2015

Published online: 24 June 2015

\section{References}

1. Bitossi G, Giorgi R, Mauro M, Salvadori B, Dei L (2005) Spectroscopic techniques in cultural heritage conservation: a survey. Appl Spectrosc Rev 40:187-228

2. La Russa M, Ruffolo S, Barone G, Mirocle C, Mazzoleni P, Pezzino A (2009) The use of FTIR and micro-FTIR spectroscopy: an example of application to cultural heritage. Int J Spectrosc 2009:893528-1-893528-5. doi:10.1155/2009/893528

3. Pérez JL, Robador M, Jiménez M, Martínez J, Garofano I, Odriozola C et al (2013) Non-invasive analytical techniques applied to characterize the components of ancient golden medallions. Herit Sci 1:4

4. Miliani C, Domenici D, Clementi C, Presciutti F, Rosi F, Buti D et al (2012) Colouring materials of pre-Columbian codices: non invasive in situ spectroscopic analysis of the Codex Cospi. J Archaeol Sci 39:672-679

5. Trojanowicz M (2008) Analytical microtechniques in archeometry. Microchim Acta 162:287-288

6. Hocquet FP, Gamir HP, Marchal A, Clar M, Oger C, Strivay D (2006) A remote controlled XRF system for field analysis of cultural heritage objects. X-Ray Spectrom 37:304-308

7. Gargano M, Ludwig N, Pandini D (2012) Use of optical fibre in spectrometry and colorimetry with remote probes. J Int Colour Assoc 8:36-43

8. De la Garza M, Bernal G, Cuevas M (2012) Palenque-Lakamha'. Una presencia inmortal del pasado indígena. Fondo de Cultura Económica, Mexico

9. Ruz A (1956) Exploraciones arqueológicas en Palenque, temporada de 1954-1955. Boletín bibliográfico de Antropología Americana 18:126-129

10. Ruz A (1962) Exploraciones arqueológicas en Palenque, 1957. Anales del Instituto Nacional de Antropología e Historia, pp 63-64

11. Ruz A (1957) La civilización de los antiguos Mayas. Instituto Nacional de Antropologia e Historia, Mexico, 71

12. Lopez JF (2001) El descubrimiento de la tumba I del Templo de la Calavera y su contexto arquitectónico en Palenque, Chiapas. Pueblos y fronteras Instituto de Investigaciones Antropológicas, Universidad Nacional Autonoma de Mexico, Mexico, pp 115-129

13. Bernal G (2006) El trono de K'inich Ahkal Mo’Nahb. Una inscripión glífica del Templo XXI de Palenque. Universidad Nacional Autonoma de Mexico, Mexico

14. Rivera A, Rainer $L$ (2003) Archaeological investigations in the Holmul Region, Peten. Results of the fourth season. Conservation reports, FAMSI

15. Andrieu C, Forné M (2009) Producción y distribución del jade en el mundo Maya: Talleres, fuentes y rutas de intercambio en su contexto interregional vista desde Cancuen. En XXIII Simposio de Investigaciones Arqueológicas en Guatemala, Museo Nacional de Arqueología y Etnología, Guatemala, pp 946-955

16. Taube K (2005) The symbolism of jade in classic maya religion. Ancient Mesoamerica 16(01):23-50

17. Taube K, Hruby Z, Romero L (2005) Jadeite sources and ancient workshops: archaeological reconnaissance in the upper Río El Tambor, Guatemala, FAMSI Reports
18. Rochette ET, Pellecer Alecio M (2006) Investigating jade prestige goods production, Middle Motagua Valley, Guatemala, FAMSI Reports

19. Barnhart E (2001) The Palenque mapping project: settlement and urbanism at an ancient maya city. Doctor of Philosophy Thesis, University of Texas at Austin, Austin, 102

20. Ostrooumov M (2007) Espectrometría infrarroja de reflexión en mineralogía avanzada, gemología y arqueometría. Instituto de Geofísica, Universidad Nacional Autonoma de Mexico, Mexico

21. Ruvalcaba JL, Ramírez D, Aguilar V, Picazo F (2010) SANDRA: a portable XRF system for the study of Mexican cultural heritage. X-Ray Spectrom 39:338-345

22. Centeno S, Williams V, Speakman R (2011) Characterization of surface decorations in Prehispanic archaeological ceramics by Raman spectroscopy, FTIR, XRD and XRF. Vib Spectrosc 58:119-124

23. Janssens K, Vittiglio G, Deraedt I, Aerts A, Vekenmans B, Vincze L et al (2000) Use of microscopic XRF for non-destructive analysis in art and archaeometry. X-Ray Spectrom 29:73-91

24. ANDREAH Proyect. http://www.fisica.unam.mx/andreah/

25. Kesiter E, Bear A, Rothenberg A, Wells C (2010) Experimental analysis of archaeological soils from Honduras using portable X-ray fluorescence spectrometry. University of South Florida, Tampa

26. Johnston F (2001) Color science in the examination of museum objects. Non-destructive procedures. The Getty Institute, Los Angeles, pp 15-56

27. Harlow G (1991) Hard Rock: a mineralogist explains the origin of Mesoamerican jade. Nat History 8(91):4-10

28. Santa Cruz R, Ruvalcaba JL (2012) Determinación de minerales de jade y otros minerales asociados con "piedras verdes" usando técnicas de Rayos $X$. In: El jade y otras piedras verdes. Perspectivas interdisciplinarias e interculturales. Instituto Nacional de Antropología e Historia, CONACULTA, Mexico, pp 17-36

29. Ruvalcaba JL, Daneels A, Vaggi M, Aguilar M (2010) Non-destructive characterization of green stone pieces from La Joya Site, Veracruz, Mexico. In: Ruvalcaba JL, Reyes J, Arenas JA, Velázquez A (eds) 2nd Latin-American Symposium on Physical and Chemical Methods in Archaeology, Art and Cultural Heritage Conservation (LASMAC 2009). Selected Papers. Universidad Nacional Autónoma de México, Universidad Autónoma de Campeche, Instituto Nacional de Antropología e Historia, Mexico, pp 49-55

30. Ruvalcaba JL, Filloy L, Vaggi M, Tapia H (2010) Estudio no destructivo in situ de la Máscara de Malinaltepec. In: La Máscara de Malinaltepec, S. Martínez del Campo coord., Instituto Nacional de Antropología e Historia, CONACULTA. Mexico, pp 153-167

31. Mei OYC, Qi LJ, Hansheng L, Kwok B (2003) Recent studies on inky black omphacite jade, a new variety of pyroxene jade. J Gemm 28(6):337-344

32. Hair J, Black W, Babin B, Anderson R (2009) Multivariate data analysis. Exploratory factor analysis. Prentice Hall, Upper Saddle River

33. Sanmartín P, Vázquez D, Silva B, Prieto B (2012) Color studies in Cultural Heritage: colorimetric techniques applied to early detection of biological colonization. Santiago de Compostela, Research Advances for the Conservation of Cultural Heritage, Universidade de Santiago de Compostela, Santiago de Compostela, 141

\section{Publish with ChemistryCentral and every scientist can read your work free of charge \\ "Open access provides opportunities to our colleagues in other parts of the globe, by allowing anyone to view the content free of charge."}

W. Jeffery Hurst, The Hershey Company.

- available free of charge to the entire scientific community

- peer reviewed and published immediately upon acceptance

- cited in PubMed and archived on PubMed Central

- yours - you keep the copyright

Submit your manuscript here:

http://www.chemistrycentral.com/manuscript/<smiles>c1ccccc1</smiles>

Chemistry Central 